\section{Inheritance of Plant and Ear Height in Maize (Zea Mays L.)}

\section{Zsuzsanna Zsubori - Zsuzsanna Gyenes-Hegyi - Ottó Illés - István Pók - Ferenc Rácz - Csaba Szőke}

Agricultural Research Institute of the Hungarian Academy of Sciences, Martonvásár

\begin{abstract}
SUMMARY
Plant and ear height are very important characters not only for describing new varieties of maize (Zea mays L.), but for green and dry matter production, and even for grain yield. Significant positive correlations have been reported by various authors between plant height and stover yield, plant height and dry matter yield, and plant height and grain yield. The height of the main ear is also correlated to plant height. It depends on the variety or the environment, but is likely to be the same height within a population. Many environmental and agronomical factors (e.g. plant density, fertilization, pests and diseases) influence the expression of these characters, which are not quality traits. Their expression is controlled by many genes and by the interactions between these genes. The heritability of these traits is high and they show significant genotypic variability and positive heterosis, as reported in many research publications.
\end{abstract}

\section{INTRODUCTION}

As a part of breeding, maintaining and improving new lines and varieties, breeders must provide the qualifiers with an exact description of the morphology, performance and quality traits of the plant. The adjudication of phenotypic traits is made following the directives of the international UPOV agreements. According to these directives, new varieties must satisfy three requirements: Distinctness, Uniformity and Stability (DUS). These investigations play a very important role in qualifying new varieties and cover not only morphological characteristics but physiological and biochemical traits as well (e.g. isoenzymes). Directives concerning the morphological characters of maize (Zea mays L.) are contained in UPOV TG/2, which includes plant height in the $1^{\text {st }}$ group, as a genetically complex, environmentally stable trait. Instead of the height of the main ear, they use the plant/ear height ratio. Both characters have to be measured at the same time, in the middle of the waxy stage. In order to differ from other varieties, the minimum difference from the experimental mean must be at least 15 or $20 \%$. The authorities offer plant height as an aspect of grouping varieties. The aim of this study was to overview what components this simple trait consists of, and what genetic and environmental factors influence its expression and inheritance.

\section{Morphology of the maize plant}

Maize (Zea mays L.) is one of the most robust plants of the Gramineae genus. Its stover architecture is similar to that of other grasses (Surányi and Mándy, 1955). The stalk is cylindrical, dense and spongoid inside, and divided into parts called internodes by the nodes. The number of nodes is 8 to 40 , depending on the variety. Below the ground, there are about 3-10 nodes close to each other, and above the ground $6-30$ or more. The varieties grown in Hungary have 6-7 nodes under the ground and 912 above the ground. The height of the stalk is determined by the number and length of the internodes. In this way, plant height can vary from $0.3 \mathrm{~m}$ to $7.0 \mathrm{~m}$, depending on the variety and growing conditions. Usually, early maturing varieties are shorter, and late maturing ones are taller. In a tropical climate, where the growing season may be as long as 11 months, some late maturing varieties reach a height of $7 \mathrm{~m}$. The varieties grown in Hungary are usually 1.2-3.0 m high (Györffy et al., 1965).

Leaves emerge from the nodes of the stalk or primary stover, and their open husks enfold the whole stalk. Secondary stovers emerge from the axils of the leaves. These are much shorter than the primary stover and carry the female inflorescences, or ears. Stovers emerging from the axil of the lowest leaf are called tillers. They sometimes reach the height of the main stover and may also have ears, but their inflorescences are usually hermaphrodites (Andrejenko and Kuperman, 1961). The upper ear is called the main ear. During the growing season only the upper 1 or 2 ears are able to develop completely, except in "prolific" varieties which may have more ears. These varieties could play an important part in breeding for higher yield (Motto and Moll, 1983).

The height of the main ear is a very important characteristic for breeding. The higher it is, the more ears can develop from the nodes below. However, if it is too high the weight of the ear may bend the stalk or even break it. Although lower ear height is unfavourable for yield and makes harvesting difficult, it does protect the stalk from excessive weight. Attempts have been made to breed in both directions, but practical experience shows that the ideal height is somewhere in between - neither too high, nor too low. It is extremely important for the ears to be at the same height within a population.

In order to fulfil this requirement, homogenous populations or varieties are needed. Hybrids are usually as balanced as inbred lines, because in the $F_{1}$ generation Mendel's rule of uniformity is predominant. As a result of inbreeding, plant height and ear height decrease, and the population becomes more and more homogeneous, until it reaches the "inbred minimum". Producing hybrids by crossing 
has the opposite effect: plant height and ear height increases, but only in the first $\left(\mathrm{F}_{1}\right)$ generation (Győrffy et al., 1965).

Nevertheless, plant and ear height not only depend on the genetic background of the varieties, but are also influenced by many environmental effects and by the growing method.

\section{Environmental effects}

\subsection{Size, plant density}

Plant density influences lighting conditions and thereby the rate of growth (Andrejenko and Kuperman, 1961). Owing to increased plant density, plant height and ear height may increase as the plants compete for light (Park et al., 1989; Mason et al., 1974). Taller plants with more leaves need a larger growing area and lower plant density than shorter ones (Begna et al., 2000). The size of the plant (height, weight, etc.) is in positive correlation with the length of the vegetative phase and the dry matter yield: taller hybrids produce a higher dry matter yield. However, the translocation rate of assimilates to the kernels of shorter hybrids was found to be greater than that of taller ones (Begna et al., 2000). This was also reflected in the harvest indices. Mason et al. (1974) reported that dry matter yield showed a significant positive correlation to plant height and to ear height.

\subsection{Growing conditions}

Habitat has a considerable effect on the plant and ear height (El-Sherbieny et al., 1991). There is a significant difference between plants grown in different areas, even within the same variety $(\mathrm{Wu}$, 1988). The genotype $\times$ year interaction is not significant for these traits (Russell, 1976). Plant height is principally determined by the variety and sowing date (Baktash and Mazaal, 1985). Early sowing is ideal for most characters, especially plant height (Kamel et al., 1979).

The tilling $\times$ hybrid interaction was reported to be significant for plant height by some authors (Newhouse and Crosbie, 1986), and insignificant by others (Hesterman et al., 1988). Similarly, the increasing $\mathrm{N}$ level of the soil had no effect on plant height in some experiments (Mason et al., 1974), and had a significant positive effect in others (Nawar et al., 1992). Poor aerobic conditions in the soil have a negative effect on this trait (Reed, 1946).

\subsection{Pests and diseases}

As a result of damage by pests and diseases, plant height may decrease to a great extent. Baggett and Kean (1989) found a significant correlation between the mildew infection rate and decreased plant height. Lara et al. (1985) found the same correlation for corn earworm (Heliothis zeae) resistance. One of the most important and most investigated pests of maize is the European corn borer, ECB (Ostrinia nubilalis). ECB usually infects taller plants in order to provide its larvae with more food. There are fewer larvae on shorter plants, but this may be attributed to the physiological maturity state of the maize plant (Guthrie et al., 1983). Plant height decreases as the number of eggs per plant increases, through the damage caused by the larvae (Davis et al., 1978). In the experiments of Williams and Davis (1984), plant height and yield decreased in susceptible hybrids as the infestation level increased, while in resistant plants neither plant height nor yield was reduced at any level of infestation. The differences in plant and ear height between resistant and susceptible synthetic populations are due to gene frequency changes (Russell et al., 1979).

\section{Genetic effects}

\subsection{Special genes}

Some plants grow shorter than other plants in the population. These are referred to as dwarf types. Dwarfism can be caused by viruses, mutations or strong environmental effects (stress). Plants containing the brachytic-2 (br2) dwarfing gene, which shortens the internodes below the ear, were 25-30\% shorter (Piovarci, 1977), or even 50-60\% shorter (Koraiem et al., 1978) than normal plants. Inspite of this gene, they produced the same or almost the same yield as their normal counterparts. This is why using these dwarf lines in breeding facilitates selection for lower ear height without significant yield losses. Another type of dwarfism, supposedly caused by the simultaneous effect of many genes, shortens the internodes only above the ear, so that plant height decreases without changing the ear height or other parts of the plant (Legg and Fleming, 1973).

Selection for cold tolerance also decreases the plant height and causes early flowering (Mock and Bakri, 1976). Cytoplasmic male sterile plants are shorter than normal plants (Ohmasa et al., 1976), as are various endosperm mutants (Pucaric et al., 1975). In the experiments of Jurado-Tovar and Compton (1974) the increasing level of competition diminished differences in plant height among the competing hybrids. As an effect of the leafy (lfy) gene, the number of leaves, the length of the internodes and the plant height increase. LFY hybrids are significantly taller than normal hybrids maturing at the same time (Pintér et al., 1999). Narrow leaf (nl1) mutants are shorter than others (Beavis et al., 1991).

\subsection{Effect of selection}

During selection, other characteristics may change, together with the improved trait. Selection for earliness, for example, decreases plant and ear height, according to many authors (Nyhus et al., 1989; Subandi, 1985; Troyer and Larkins, 1985). It is probably due to gene frequency changes (Nyhus et al., 1989). In contrast, selection for higher yield increases plant and ear height (Thompson, 1983). 
There are some cases when plant height increases while ear height decreases (Yap and Tan, 1974). Both characteristics show significant inbreeding depression (Cornelius and Dudley, 1974).

Many breeders have studied selection for lower ear height. Maybe the most outstanding of them is Harville (1977), who produced many early and late maturing, low-eared varieties by recurrent selection. These low-eared varieties were not significantly shorter than before selection (Harville et al., 1978). The experiments of Josephson and Kincer (1973) gave the same result. Crossing with desirable higheared lines resulted in lower and more homogeneous ear height in the progenies, which facilitates mechanical harvesting (Harville et al., 1979).

\subsection{Correlations}

Plant height is strongly associated with the flowering date, both morphologically and ontogenetically, because internode formation stops at floral initiation, which means that earlier flowering maize is usually shorter (Troyer and Larkins, 1985). Breeders used to think that earliness and high yield stood in reciprocal ratio to each other. In Hungary, Fleischmann (1974) proposed first the necessity of breaking this negative correlation. Modern varieties produce high yields despite early flowering. There is also a correlation between earliness and ear height. The higher the ear is, the later the plant matures (Surányi and Mándy, 1955), but earliness and lower ear height have no absolute reciprocality.

There are correlations between many other traits and plant height. The number of leaves (Allen et al., 1973) and the grain yield (McKee et al., 1974) are significantly correlated with plant height. In sweet corn, the grain yield (Tan and Yap, 1973) and ear length (Hansen, 1976) show significant positive correlations with plant and ear height. In popcorn, the grain yield has a positive correlation and the popping expansion a negative correlation with both characters (Verma and Singh, 1979). Obilana and Hallauer (1974) found a significant correlation between plant height and ear height in unselected inbreds.

\subsection{QTLS}

Morphological traits and the phenotype are determined by the genotype. Genes are located in different regions of the chromosomes and there are various interactions between them. Genes determining quantitative traits are located in QTLs (Quantitative Trait Loci). A great number of QTLs have been mapped so far. Edwards et al. (1987) identified QTLs for plant height in maize. Hui et al. (1997) found 30 QTLs for plant and ear height and resistance to ECB. According to Veldboom et al. (1994), QTLs for plant height are in close proximity to loci of qualitative traits affecting plant height. Lee and Veldboom (1993) found a marker on the long arm of chromosome 1 which is closely linked to a QTL for plant height.This probe defines an interval on the genetic map which accounts for $40 \%$ of the phenotypic variation for plant height. Berke and Rocheford (1995) found 18 marker loci clustered in 11 chromosome regions significantly associated with plant height, and 14 markers clustered in 9 regions significantly associated with ear height. Schön et al. (1993) revealed that genomic regions on chromosome arms 1S, 3L and 9L significantly affect plant height. On chromosome arm 3L they found evidence for an interaction between genes conferring resistance to the second generation of ECB and to plant height. Koester et al. (1993) identified QTLs for plant height and flowering time on chromosomes 1,8 and 10 , and published a table comparing their own results with those of other authors.

Plant height is usually considered to be a simple inherited trait, determined by only a few genes. According to Sheridan (1988), there are at least 27 loci influencing the quantitative expression of this trait. Beavis et al. (1991) identified 14 QTLs, most of them linked to the loci of qualitative traits. A plant height QTL on chromosome 9, for example, is in close proximity to the GA (gibberellic acid) mutant gene d3. This tends to support Robertson's (1985) hypothesis, who described plant height as a quantitative trait with known qualitative mutants.

The QTL $\times$ environment interaction is not significant (Kraja and Dudley, 2000).

\subsection{Heritability and mode of inheritance}

The heritability of plant height is high, with an $\mathrm{h}^{2}$ value of about 0.8 (Schön et al., 1993; Daniel and Bajtay, 1975). In diallel trials, it showed significant genotypic variance and strong positive heterosis. Bajtay and Daniel (1976) found positive heterosis even when crossing sweetcorn inbreds. The reason for this great heterosis in plant height could be overdominance, the accumulation of dominant alleles in different loci or epistasis (Hallauer and Miranda, 1981).

Nawar et al. (1991) estimated the genotypic and phenotypic variances and co-variances for plant height, and there were many authors who found significant variance for this trait (Malvar et al., 1996; Hansen and Baggett, 1977; Subandi and Compton, 1974). The significant variance existing in plant and ear height is due to the multiplication of alleles and to overdominance, according to many research findings. Either dominance (Guo et al., 1986) or additive effects (Russell, 1976) are considered more important in the expression of plant and ear height, though some authors assign the differences in plant and ear height to extrachromosomal effects (Baynes and Brawn, 1973).

\section{CONCLUSIONS}

As is clear from the paper, this subject has been studied in depth by many researchers in recent decades, especially in the 70 s and 80 s. Nevertheless, the subject has lost none of its topicality. As new varieties are developed, plant height is considered not only in the course of morphological descriptions, but 
also during the development of other traits, since it is closely connected with such important characters as flowering date and yield. Research on plant height and ear height has been continued in recent years, both in major foreign institutes (Troyer, 1990; Austin et al., 2001; Begna et al., 2001, etc.) and in Hungary (Gyenes-Hegyi et al., 2002).

\section{REFERENCES}

Allen, J. R.-McKee, G. W.-McGahen, J. H. (1973): Leaf number and maturity in hybrid corn. Agron. J., 65. 233-235.

Andrejenko, S. S.-Kuperman, F. M. (1961): A kukorica élettana. (Physiology of Maize.) Mg. Kiadó, Budapest

Austin, D. F.-Lee, M.-Weldboom, L. R. (2001): Genetic mapping in maize with hybrid progeny across testers and generations: plant height and flowering. Theor. Appl. Gen. 102. 163-176.

Baggett, J. R.-Kean, D. (1989): Reduction of plant height by head smut infection in sweet corn cultivars. HortScience 24. 497499.

Bajtay, I.-Daniel, L. (1976): Gazdasági tulajdonságok alakulása 9 csemegekukorica-genotípus (Zea mays L. conv. saccharata Koern.) diallél keresztezésében. I. Összehasonlító kísérletek. (Analysis of agronomic characters in a diallel cross of nine genotypes of sweet corn (Zea mays L. conv. saccharata Koern.). I. Comparative trials.) ZKI Bbulletinje 11. 45-51.

Baktash, F. Y.-Mazaal, A. D. (1985): Effect of seeding dates and genotypes on corn grain yield. J. of Agr. and Water Resources Res. 4. 1-11.

Baynes, R. A.-Brawn, R. I. (1973): Influence of cytoplasmic effects on some agronomic characters in corn. Can. J. of Plant Sci. 53. 101-104.

Beavis, W. D.-Grant, D.-Albertsen, M.-Fincher, R. (1991): Quantitative trait loci for plant height in four maize populations and their associations with qualitative genetic loci. Theor. Appl. Genet. 83. 141-145.

Begna, S. H.-Hamilton, R. I.-Dwyer, L. M.-Stewart, D. W.-Smith, D. L. (2000): Variability among maize hybrids differing in canopy architecture for above-ground dry matter and grain yield. Maydica 45. 135-141.

Begna, S. H.-Hamilton, R. I.-Dwyer, L. M.-Stewart, D. W.Cloutier, D.-Assemat, L.-Foroutan pour, K.-Smith, D. L. (2001): Morphology and yield response to weed pressure by corn hybrids differing in canopy architecture. Eur. J. of Agronomy, 14. 293-302.

Berke, T. G.-Rocheford, T. R. (1995): Quantitative trait loci for flowering, plant and ear height, and kernel traits in maize. Crop Sci. 35. 1542-1549.

Cornelius, P. L.-Dudley, J. W. (1974): Effects of inbreeding by selfing and full-sib mating in a maize population. Crop Sci. 14. 815-819.

Daniel, L.-Bajtay, I. (1975): Néhány mennyiségi tulajdonság alakulása 11 csemegekukorica (Zea mays L. conv. saccharata Koern.) beltenyésztett törzs diallél keresztezésében. (The expression of some quantitative characters in a diallel cross of eleven inbred lines of sweet corn (Zea mays L. conv. saccharata Koern.)) Növénytermelés 24. 285-294.

Davis, F. M.-Scott, G. E.-Williams, W. P. (1978): Southwestern corn borer: effect of levels of first brood on maize. J. of Econ. Entomology 71. 244-246.

Edwards, M. D.-Stuber, C. W.-Wendell, J. F. (1987): Molecular marker-facilitated investigations of quantitative trait loci in maize. I. Numbers, genomic distribution, and types of gene action. Genetics 116. 113-125.

El-Sherbieny, H. Y.-El-Itriby, H. A.-Mahgoub, G. M. A.-Ismail, A. A. (1991): Improvement of a commercial maize single cross by improving its component inbreds. II. Improving inbred line Sids 62, the male parent of single cross 9. Bull. of Fac. of Agr. Univ. of Cairo 42. 971-980.

Fleischmann, R. (1947): Kukorica. Zea mays L. (Maize. Zea mays L.) in Villax Ö.: Növénynemesítés II. (Plant breeding II.) Mosonmagyaróvár

Guo, P. Z.-Gardner, C. O.-Obaidi, M. (1986): Genetic variation and gene effects controlling prolificacy and other traits in maize (Zea mays L.). Acta Gen. Sinica 13. 35-42.

Guthrie, W. D.-Barry, B. D.-Reed, G. L. (1983): Effect of plant height and the yellow-green gene in maize on leaf feeding by first-generation European corn borers (Lepidoptera: Pyralidae). J. of Econ. Entomology 76. 818-820.

Gyenes-Hegyi, Z.-Pók, I.-Kizmus, L.-Zsubori, Z.-Nagy, E.Marton, L. C. (2002): Plant height and height of the main ear in maize (Zea mays L.) at different locations and different plant densities. Acta Agr. Hungarica 50. 75-84

Győrffy, B.-I'só, I.-Bölöni, I. (1965): Kukoricatermesztés. (Corn growing.) Mezőgazdasági Kiadó, Budapest

Hallauer, A. R.-Miranda, J. B. (1981): Quantitative genetics in maize breeding. Iowa St. Univ. Press, Ames, Ia

Hansen, L. A.-Baggett, J. R. (1977): Reciprocal differences for plant and ear characteristics in sweet corn. HortScience 12 . 60-62.

Hansen, L. A. (1976): The inheritance of ten quantitative characteristics in sweet corn (Zea mays L.). Dissertation Abstr. Int. 37. 69B

Harville, B. G. (1977): Inheritance of ear height and associated characters of corn (Zea mays L.) Dissertation Abstr. Int. 37. 3699-3700B

Harville, B. G.-Josephson, L. M.-Kincer, H. C. (1978): Diallel analysis of ear height and associated characters in corn. Crop Sci. 18. 273-275.

Harville, B. G.-Josephson, L. M.-Kincer, H. C. (1979): Breeding corn hybrids for low-ear placement. Tennessee Home and Farm Sci. 111. 2-4.

Hesterman, O. B.-Pierce, F. J.-Rossman, E. C. (1988): Performance of commercial corn hybrids under conventional and no-tillage systems. J. of Production Agr. 1. 202-206.

Hui D. F.-Jiang, C. J.-Mo, H. D. (1997): Comparison among mapping methods for detecting QTLs and estimating their effects. Acta Agr. Sinica 23. 129-136.

Josephson, L. M.-Kincer, H. C. (1973): Selection for low ear placement in corn. Agron. Abstr. 8.

Jurado-Tovar, A.-Compton, W. A. (1974): Intergenotypic competition studies in corn (Zea mays L.) I. Among experimental hybrids. Theor. Appl. Genet. 45. 205-210.

Kamel, M. S.-El-Kadi, D. A.-Mahmoud, E. A.-Ba-Momen, A. M. (1979): Effect of sowing dates on some developmental characteristics of three corn cultivars. Res. Bull. Fac. of Agr. Ain Shams Univ. 1095, 18.

Koester, R. P.-Sisco, P. H.-Stuber, C. W. (1993): Identification of quantitative trait loci controlling days to flowering and plant height in two near isogenic lines of maize. Crop Sci. 33. 12091216 . 
Koraiem, Y. S.-Bary, A. A.-Shalaby, A. A.-Khalifa, K. I. (1978): Effect of brachytic-2 dwarfing gene on some corn populations (Zea mays L.). Alexandria J. of Agr. Res. 26. 73-78.

Kraja, A. T.-Dudley, J. W. (2000): QTL analysis of two maize inbred line crosses. Maydica 45. 1-12.

Lara, F. M.-Osuna, J. A.-Araujo, S. M. C.-De Banzatto, D. A.Ayala-Osuna, J.-De Araujo, S. M. C. (1985): Evaluation of maize cultivars for agronomic characters and resistance to Heliothis zea (Boddie, 1850) (Lepidoptera, Noctuidae). Anais da Sociedade Entomologica do Brasil 14. 111-119.

Lee, M.-Veldboom, L. R. (1993): Quantitative genetic variation near an1 and bx1. Maize Gen. Coop. Newsletter 67, 6 .

Legg, J. G.-Fleming, A. A. (1973): Inheritance of a new brachyism in corn, Zea mays L. Crop Sci. 13. 322-324.

Malvar, R. A.-Ordas, A.-Revilla, P.-Cartea, M. E. (1996): Estimates of genetic variances in two Spanish populations of maize. Crop Sci. 36. 291-295.

Mason, L.-Mondart, C. L. Jr.-Chaney, C. R.-Martin, P.-Milam, M. (1974): Corn forage as affected by plant population, nitrogen rate and hybrid on Olivier soil. Bulletin, Agr. Exp. Stat., Louisiana St. Univ. 677, 23.

McKee, G. W.-McGahen, J. H.-Peiffer, R. A.-Allen, J. R. (1974): Interrelationships of maturity, leaf area inex, time of black layer formation, heat units and yield of 120 corn hybrids. Agron. Abstr. 87.

Mock, J. J.-Bakri, A. A. (1976): Recurrent selection for cold tolerance in maize. Crop Sci. 16. 230-233.

Motto, M.-Moll, R. H. (1983): Prolificacy in maize: a review. Maydica 28. 53-76.

Nawar, A. A.-Ibrahim, M. E.-Attia, M. B. (1992): Grain yield, yield components and infestation rates of corn borers and aphid of maize genotypes as influenced by nitrogen fertilization. Egyptian J. of Agron. 17. 41-58.

Nawar, A. A.-Ibrahim, M. E.-Khalil, A. N. M. (1991): The efficiency of three conventional selection indices in corn. Annals of Agr. Sci. Moshtohor 29. 63-75.

Newhouse, K. E.-Crosbie, T. M. (1986): Interactions of maize hybrids with tillage systems. Agron. J. 78. 6. 951-954.

Nyhus, K. A.-Russell, W. A.-Guthrie, W. D. (1989): Changes in agronomic traits associated with recurrent selection in two maize synthetics. Crop Sci. 29. 269-275.

Obilana, A. T.-Hallauer, A. R. (1974): Estimation of variability of quantitative traits in BSSS by using unselected maize inbred lines. Crop Science 14. 99-103.

Ohmasa, M.-Watanabe, Y.-Murata, N.-Omasa, M. (1976): A biochemical study of cytoplasmic male-sterility in corn: alteration of cytochrome oxidase and malate dehydrogenase activities during pollen development. Japanese J. of Breeding I. Z. 26. 40-50.

Park, K. Y.-Kang, Y. K.-Park, S. U.-Moon, H. G. (1989): Effects of planting density and tiller removal on growth and yield of sweet corn hybrids. Korean J. of Crop Sci. 34. 192-197.

Pintér, J.-Szundy, T.-Marton, L. Cs.-Hadi, G. (1999): LFY gén a martonvásári kukoricanemesítés szolgálatában. (Use of LFY gene in corn breeding in Martonvasar.) MartonVásár 99. 1. 22-23.

Piovarci, A. (1977): Dwarfing gene brachytic-2 in modifying plant architecture of corn (Zea mays L.). IX. Meeting of Eucarpia maize and sorghum section, USSR, Krasnodar. I. Development and improvement of initial stock for maize breeding 35-36.

Pucaric, A.-Crane, P. L.-Glover, D. V. (1975): Stand, early growth and plant and ear height of endosperm mutants and normal maize hybrids under field conditions. Zeitschrift fur Acker und Pflanzenbau 141. 317-325.

Reed, W. E. (1946): A növények hatása a Dundick iszapos agyagtalaj fizikai tulajdonságaira és a talajszellözés hatása a növények növekedésére és összetételére. (Effect of plants on physical characters of Dundick soil and effect of soil air conditions on the growth and chemical composition of plants.) In Andrejenko, Sz. Sz.-Kuperman, F. M. (1961): A kukorica élettana. (Physiology of corn) Mg. Kiadó, Budapest

Robertson, D. S. (1985): A possible technique for isolating genomic DNA for quantitative traits in plants. J. Theor. Biol. 117. 1-10.

Russell, W. A. (1976): Genetic effects and genetic effect X year interactions at three gene loci in sublines of a maize inbred line. Canadian J. of Gen. and Cytology 18. 23-33.

Russell, W. A.-Lawrance, G. D.-Guthrie, W. D. (1979): Effects of recurrent selection for European corn borer resistance on other agronomic characters in synthetic cultivars of maize. Maydica 14. 33-47.

Schön, C. C.-Lee, M.-Melchinger, A. E.-Guthrie, W. D.Woodman, W. L. (1993): Mapping and characterization of quantitative trait loci affecting resistance against secondgeneration European corn borer in maize with the aid of RFLPs. Heredity 70. 648-659.

Sheridan, W. F. (1988): Maize developmental genetics: genes of morphogenesis. Annu. Rev. Genet. 22. 353-385.

Subandi-Compton, W. A. (1974): Genetic studies in an exotic population of corn (Zea mays L.) grown under two plant densities. 1. Estimates of genetic parameters. Theor. Appl. Genet. 44. 153-159.

Subandi (1985): Selection for early silking and maturity in three populations of corn (Zea mays L.) in Bogor, Indonesia. Indonesian J. of Crop Sci. 1. 65-72.

Surányi, J.-Mándy, Gy. (1955): A kukorica. (Corn.) Magyarország kultúrflórája. (Culture flora of Hungary) Akadémiai Kiadó, Budapest

Tan, S. L.-Yap, T. C. (1973): Performance of intervarietal crosses of maize and sweet corn and correlations among agronomic characters. Malaysian Agric. Res. 2. 1-5.

Thompson, S. A. (1983): Mass selection for prolificacy in corn at high and low plant densities: cycle means and genotypic variances. Dissertation Abstracts International 43. 2414B

Troyer, A. F.-Larkins, J. R. (1985): Selection for early flowering in corn: 10 late synthetics. Crop Sci. 25. 695-697.

Troyer, A. F. (1990): Selection for early flowering in corn: three adapted synthetics. Crop Sci. 30. 896-900.

Veldboom, L. R.-Lee, M.-Woodman, W. L. (1994): Molecular marker-facilitated studies in an elite maize population: I. Linkage analysis and determination of QTL for morphological traits. Theor. Appl. Genet. 88. 7-16.

Verma, R. K.-Singh, T. P. (1979): Interrelations among certain quantitative traits in pop-corn. Mysore J. of Agr. Sci. 13. 1518.

Williams, W. P.-Davis, F. M. (1984): Reaction of a resistant and a susceptible corn hybrid to various southwestern corn borer infestation levels. Agron. J. 76. 855-857.

Wu, Z. K. (1988): Study of eight agronomic characters in corn under two environments. Acta Agr. Sinica 14. 39-45.

Yap, T. C.-Tan, S. T. (1974): Evaluation of recurrent selection based on roguing, S1 progeny test and S1 line breeding in a sweet corn variety. Malysian Agricultural Research 3. 222226 . 